\title{
DA TAXATIVIDADE PENAL E O CONCEITO ATUAL DE FAMÍLIA - A ASSUNÇÃO DO IDEAL DE COERÊNCIA E INTEGRIDADE DO DIREITO ATRAVÉS DA INTERPRETAÇÃO PRINCIPIOLÓGICA
}

\section{DE LA TAXATIVIDADE CRIMINAL Y EL CONCEPTO ATUAL DE FAMILIA - LA ASUNCIÓN DEL IDEAL DE COHERENCIA Y INTEGRIDAD DEL DERECHO A TRAVÉS DE LA INTERPRETACIÓN PRINCIPIOLÓGICA}

\author{
${ }^{1}$ Laira Carone Rachid Domith \\ ${ }^{2}$ Gabriel Senra E Pádua
}

\section{RESUMO}

Atualmente o conceito de "família" possui um significado jurídico distinto do que possuía em 1940, quando apenas o casamento era legítimo para fins de sua constituição. Ainda que o Direito Penal proíba a analogia e a interpretação extensiva in malam partem, a atualização do conceito de família foi feita pela $\mathrm{CF} / 88$, que passou a prever o reconhecimento jurídico das famílias matrimonial, monoparental e decorrentes de união estável. No contexto do Neoconstitucionalismo, torna-se necessária a elucidação do real sentido do Princípio da Legalidade e a utilização da interpretação principiológica do Direito Penal adequando-o, caso a caso, à complexidade da sociedade Moderna.

Palavras-chave: Neoconstitucionalismo. pós-positivismo, Interpretação principiológica. princípio da legalidade penal. casamento. união estável

\section{RESUMEN}

Actualmente el concepto de "familia" tiene significado jurídico diferente a lo que tenía en 1940, cuando sólo podría ser constituida legítimamiente por el casamiento. Aunque la ley penal prohiba la analogía y la interpretación extensiva in mallam partem, la actualización del concepto de familia fue hecha por la $\mathrm{CF} / 88$, que renoce las familias matrimoniales, monoparentales y derivadas de la unión estable. En el contexto del Neoconstitucionalismo, se hace necessaria la elucidación del sentido real del principio de la legalidad penal y el uso de la interpretación principiológica del derecho penal adaptándolo, caso a caso, a la complejidadde la sociedad Moderna.

Palabras-claves: Neoconstitucionalismo, Postpositivismo, Interpretación principiológica, Principio de la legalidad penal, Matrimonio, Unión estable

\footnotetext{
${ }^{1}$ Mestre em Direito Público e Evolução Social pela Universidade Estácio de Sá - UNESA. Professora de Direito de Família do Curso de Direito da Faculdade Doctum de Juiz de Fora, Minas Gerais (Brasil). E-mail: lairarachid@hotmail.com

${ }^{2}$ Mestre em Hermenêutica Jurídica e Direitos Fundamentais pela Universidade Presidente Antônio Carlos UNIPAC, Minas Gerais (Brasil). Professora de Direito Penal e Processual Penal na Faculdade Doctum de Juiz de Fora e no Instituto Vianna Júnior, Minas Gerais (Brasil). E-mail: gabriel79.jf@gmail.com
} 


\section{INTRODUÇÃO}

O direito não é uma pura teoria, mas uma força viva (IHERING, 2009, p. 23).

O Direito é um fenômeno construído através da constante interação entre fatos, valores e normas (princípio e regras), num sistema permanente de inputs e outputs, portanto, dinâmico e mutante.

Ainda que o estudo do Direito, por questões de ordem prática, subdivida-se em áreas determinadas pelo tipo de fato social que provoca a construção e a incidência da norma, importante ressaltar que trata-se de uma ciência una, formada por ramos que, obrigatoriamente, devem dialogar e manter coerência entre si e, sobretudo, com a Constituição Federal.

Não obstante este dever de unicidade - já que a Constituição informa todo o ordenamento infraconstitucional -, incoerências são verificadas diuturnamente e é neste cenário que será trabalhado o descompasso entre a acepção constitucional de família e aquilo que o Código Penal compreende como sendo relações familiares.

O Código Penal de 1940 já passou por diversas atualizações pontuais decorrentes da edição de leis esparsas e o resultado disso é a convivência, dentro de um mesmo ramo do Direito, de dispositivos que ora consideram apenas o matrimônio para fins de constituição de família e incidência de agravantes ou outros desdobramentos penais; ora levam em conta a existência das uniões estáveis e homoafetivas.

Considerando que em matéria de formas constitutivas de família a Constituição Federal de 1988 pautou-se no princípio da pluralidade, o mesmo deveria ser irradiado para todo o ordenamento jurídico. Contudo, a dogmática penal é essencialmente positivista, considerando inaceitável a aplicação dos princípios ao deslinde do caso concreto sob pena de configuração de analogia in malam partem.

Tendo como pano de fundo o Neoconstitucionalismo e o Pós-Positivismo, o presente estudo pretende superar as distorções da dogmática penal com relação à sua pretensa leitura constitucional do Direito Penal. Para tanto, utilizar-se-á a interpretação principiológica, elucidando o real significado do princípio da legalidade, interpretado restritivamente pela doutrina especializada.

A pesquisa realizada foi qualitativa, essencialmente bibliográfica e documental. 


\section{DA INCOERÊNCIA INTRASISTÊMICA DO DIREITO PENAL RELATIVA À AMPLITUDE DO CONCEITO DE FAMÍLIA/RELAÇÕES FAMILIARES}

Da leitura do Código Penal e da legislação penal esparsa observa-se que existe uma preocupação relativa à proteção das relações familiares sadias, certamente em atenção ao mandamento constitucional que determina ser a família a base da sociedade, merecendo especial atenção do Estado. Assim, há previsão legal dos crimes contra o casamento, o estado de filiação, a assistência familiar, o poder familiar, a tutela e a curatela, bem como tratamento mais severo aos crimes praticados entre membros de uma mesma família.

Partindo-se do pressuposto de que os componentes de um núcleo familiar devem nutrir entre si relações de solidariedade e confiança e de que o mesmo seja locus de proteção e promoção da dignidade da pessoa humana - função social das famílias - o Código Penal prevê em seu art. 61, II, "e", que são circunstâncias que sempre agravam a pena, quando não constituem ou qualificam o crime, ter o ofensor agido contra ascendente, descendente, irmão ou cônjuge. Conforme explica ROCHA,

A circunstância de o crime ter sido praticado contra ascendente, descendente ou cônjuge agrava a pena, já que o legislador entendeu que em tais situações o agente revela maior insensibilidade moral pela violação dos sentimentos de estima e solidariedade, em regra existentes entre parentes próximos. (2004, p. 726)

Observa-se que o art. 61 do Código Penal não abarca expressamente a conduta criminosa praticada por um companheiro contra o outro em casos de uniões estável e homoafetiva. Nucci explica que

\footnotetext{
Aumenta-se a punição no caso de crime cometido contra ascendente, descendente, irmão ou cônjuge, tendo em vista a maior insensibilidade do agente, que viola o dever de apoio mútuo existente entre parentes e pessoas ligadas pelo matrimônio.

Nesse caso, trata-se de parentesco natural ou civil. Descartam-se, apenas, as relações de afinidade, como as figuras do pai ou da mãe de criação e outras correlatas. Não se aceita, também, pelo princípio da legalidade estrita que vige em direito penal, qualquer inclusão de concubinos ou companheiros (2014, p. 428).
}

No mesmo sentido, Cunha defende que "essa agravante não se aplica ao parentesco por afinidade ou à união estável, pois não se admite interpretação in malam partem, desautorizada pelo princípio da legalidade" (2015, p. 416). Seguindo esta diretriz, Masson defende que 
O fundamento dessa agravante genérica repousa na apatia moral do agente, que se prevalece de relações familiares para a prática do crime, transgredindo o dever de auxílio recíproco existente entre parentes e pessoas ligadas pelo matrimônio. O sujeito deve efetivamente aproveitar-se das facilidades que o parentesco ou matrimônio lhe proporcionam, pois caso contrário o dispositivo legal não terá incidência. (...) A união estável não autoriza a aplicação da agravante genérica, em face da inadmissibilidade da analogia in malam partem no Direito Penal (2014, p. 320).

Por fim, Greco elucida que "como a última figura da alínea $e$ faz menção ao cônjuge, não podemos nela admitir a pessoa do(a) companheiro(a), sob pena de ser realizada a chamada analogia in malam partem". Ressalta, porém, que isso "não impede que, neste caso, seja aplicada a circunstância agravante elencada pela alínea $f$, o que significa, em outras palavras, que se o agente praticar crime contra companheiro(a) sua pena será aumentada em virtude da agravante de ter o mesmo se prevalecido de relações domésticas ou de coabitação (2015, p. 648).

Contudo, há outros vários dispositivos penais que ignoram a existência de união estável e homoafetiva existente entre ofensor e ofendido, relevando apenas o vínculo matrimonial, sendo esta opção de utilização da alínea "f” do art. 61 do Código Penal restrita ao âmbito das agravantes genéricas.

Com relação ao $\S 4^{\circ}$ do art. 100 do Código Penal, por exemplo, que encontra correspondência no art. 31 do Código Processual Penal, assegura-se apenas ao cônjuge, ascendentes, descendentes e irmãos a garantia de oferecer queixa ou prosseguir na ação penal em caso de morte ou declaração de ausência do ofendido. Neste sentido, Lima entende que

Por força do disposto no art. 226, $\S 3^{\circ}$, da Constituição Federal, grande parte da doutrina insere no rol dos sucessores o companheiro. Logo, a ordem seria cônjuge (ou companheiro), ascendente, descendente ou irmão. A nosso ver, não se pode incluir o companheiro nesse rol, sob pena de indevida analogia in malam partem. A inclusão do companheiro ou da companheira nesse rol de sucessores produz reflexos no direito de punir do Estado, já que, quanto menos sucessores existirem, maior é a possibilidade de que o não exercício do direito de representação ou de queixa no prazo legal acarrete a extinção da punibilidade pela decadência. Portanto, cuidando-se de regra de direito material, não se pode querer incluir o companheiro, sob pena de indevida analogia in malam partem, malferindo o princípio da legalidade (CF, art. $5^{\circ}$, XXXIX) $(2015$, p. 244).

Também neste sentido, observa-se a previsão de incidência de outras regras inscritas no Código Penal apenas sobre os cônjuges e não sobre aqueles que optaram por formas de composição de núcleos familiares que, mesmo revestidas de publicidade, durabilidade e erigidas sobre o ânimo de constituir família (affectio familiae), não 
constituem matrimônio. Assim, na tipificação do crime de abandono de incapaz, mais precisamente no aumento da pena a ser cominada ao ofensor, observa-se que:

Art. 133, CP. Abandonar pessoa que está sob seu cuidado, guarda, vigilância ou autoridade, e, por qualquer motivo, incapaz de defender-se dos riscos resultantes do abandono:

(...)

$\S 3^{\circ}$ As penas cominadas neste artigo aumentam-se de um terço:

(...)

II - se o agente é ascendente ou descendente, cônjuge, irmão, tutor ou curador da vítima.

Na conceituação do crime de abandono material, detecta-se que o mesmo pode ser praticado apenas contra ascendente, descendente e cônjuge:

Art. 244. Deixar, sem justa causa, de prover a subsistência do cônjuge, ou de filho menor de 18 (dezoito) anos ou inapto para o trabalho, ou de ascendente inválido ou maior de 60 (sessenta) anos, não lhes proporcionando os recursos necessários ou faltando ao pagamento de pensão alimentícia judicialmente acordada, fixada ou majorada; (...).

Pena - detenção de 1 (um) ano a 4 (quatro) anos e multa, de uma a dez vezes o maior salário-mínimo vigente no País

Não obstante a ausência da previsão da união estável e da união homoafetiva nos dispositivos acima transcritos, o mesmo Diploma Legal, em outros artigos incluídos ou modificados mais recentemente através de legislação penal esparsa, prevê que:

Art. 129, CP. Ofender a integridade corporal ou a saúde de outrem:

Pena - detenção, de três meses a um ano.

(...)

$\S 9^{\circ}$ Se a lesão for praticada contra ascendente, descendente, irmão, cônjuge ou companheiro, ou com quem conviva ou tenha convivido, ou, ainda, prevalecendo-se o agente das relações domésticas, de coabitação ou de hospitalidade:

Pena - detenção, de 3 (três) meses a 3 (três) anos.

Art. 148, CP. Privar alguém de sua liberdade, mediante seqüestro ou cárcere privado:

Pena - reclusão, de um a três anos.

$\S 1^{\circ}$ A pena é de reclusão, de dois a cinco anos:

I - se a vítima é ascendente, descendente, cônjuge ou companheiro do agente ou maior de 60 (sessenta) anos;

(...)

No contexto específico dos crimes contra a dignidade sexual,

Art. 226. A pena é aumentada:

(...) 
II - de metade, se o agente é ascendente, padrasto ou madrasta, tio, irmão, cônjuge, companheiro, tutor, curador, preceptor ou empregador da vítima ou por qualquer outro título tem autoridade sobre ela;

No âmbito dos crimes de exploração sexual, tem-se que:

Art. 230. Tirar proveito da prostituição alheia, participando diretamente de seus lucros ou fazendo-se sustentar, no todo ou em parte, por quem a exerça:

Pena - reclusão, de um a quatro anos, e multa.

$\S 1^{\circ}$ Se a vítima é menor de 18 (dezoito) e maior de 14 (catorze) anos ou se o crime é cometido por ascendente, padrasto, madrasta, irmão, enteado, cônjuge, companheiro, tutor ou curador, preceptor ou empregador da vítima, ou por quem assumiu, por lei ou outra forma, obrigação de cuidado, proteção ou vigilância:

Pena - reclusão, de 3 (três) a 6 (seis) anos, e multa.

$(\ldots)$

Art. 231. Promover ou facilitar a entrada, no território nacional, de alguém que nele venha a exercer a prostituição ou outra forma de exploração sexual, ou a saída de alguém que vá exercê-la no estrangeiro.

Pena - reclusão, de 3 (três) a 8 (oito) anos

(...)

$\S 2^{\circ}$ A pena é aumentada da metade se:

(...)

III - se o agente é ascendente, padrasto, madrasta, irmão, enteado, cônjuge, companheiro, tutor ou curador, preceptor ou empregador da vítima, ou se assumiu, por lei ou outra forma, obrigação de cuidado, proteção ou vigilância; (...)

Art. 231-A. Promover ou facilitar o deslocamento de alguém dentro do território nacional para o exercício da prostituição ou outra forma de exploração sexual:

Pena - reclusão, de 2 (dois) a 6 (seis) anos

(...)

$\S 2^{\circ}$ A pena é aumentada da metade se:

(...)

III - se o agente é ascendente, padrasto, madrasta, irmão, enteado, cônjuge, companheiro, tutor ou curador, preceptor ou empregador da vítima, ou se assumiu, por lei ou outra forma, obrigação de cuidado, proteção ou vigilância; (...)

Atenta ao fato de que as formas constitutivas de família estão cada vez mais democráticas, frise-se que a Lei Maria da Penha (Lei 11.340/2006), que também situa-se no âmbito do Direito Penal, prevê que aquela deve ser compreendida como a comunidade formada por indivíduos que são ou se consideram aparentados, unidos por laços naturais, por afinidade ou por vontade expressa (art. $5^{\circ}$. , II).

Pode-se dizer que esta conceituação de família é a mais atualizada dentro do ornamento jurídico brasileiro, efetivando o princípio da pluralidade exemplificado pela Constituição Federal ao prever, ao lado do casamento, as uniões estáveis e as famílias monoparentais. 
Contudo, mesmo diante do conceito atualíssimo de família trazido pela Lei Maria da Penha, a doutrina penal esmagadoramente majoritária permanece na defesa da interpretação literal dos dispositivos do Código Penal transcritos no início deste trabalho sob o fundamento da proibição da analogia e interpretação extensiva in malam partem.

Ressalte-se que nos artigos em que a analogia entre união estável e casamento beneficiarem o réu, a mesma poderá ser empregada, a exemplo do que ocorre nos artigos 181 e 182 do Código Penal, que referem-se aos crimes contra o patrimônio:

Art. 181, CP. É isento de pena quem comete qualquer dos crimes previstos neste título, em prejuízo:

I - do cônjuge, na constância da sociedade conjugal;

II - do ascendente ou descendente, seja o parentesco legítimo ou ilegítimo, seja civil ou natural.

Art. 182 - Somente se procede mediante representação, se o crime previsto neste título é cometido em prejuízo:

I - do cônjuge desquitado ou judicialmente separado;

II - de irmão, legítimo ou ilegítimo;

III - de tio ou sobrinho, com quem o agente coabita.

Diante de todos os artigos transcritos e/ou comentados neste capítulo, observa-se que na seara do Direito Penal há falta de unidade sobre o conceito de relações familiares, já que alguns dispositivos fazem alusão à figura do cônjuge, sem mencionar a do(a) companheiro(a), chegando-se ao cúmulo da disparidade se houver comparação entre o conceito atualíssimo de família elaborado pela Lei Maria da Penha e o restante da legislação penal.

\section{DIREITO CONSTITUCIONAL E ABRANGÊNCIA DO CONCEITO DE FAMÍLIA}

O direito é como Saturno ${ }^{l}$ devorando seus próprios filhos: não pode remoçar sem fazer tábua rasa de seu próprio passado. Um direito concreto que se vangloria de sua existência para pretender uma

\footnotetext{
${ }^{1}$ Segundo Santana, "Saturno é a divindade romana mais complexa, conhecida pelos gregos como Cronos, o deus que representa o tempo. Parecia pairar sobre ele e sua família uma maldição, pois logo cedo ele expulsou o próprio pai, Urano, de sua posição soberana entre os deuses, já que o mesmo estava dominado pela insanidade, gerando muita confusão na esfera terrena. Pouco tempo depois, exercendo igualmente uma liderança tirânica, recebe uma profecia assustadora, a de que ele também seria deposto do trono por um de seus filhos. (...) Ciente da predição paterna, ele devora todos os filhos, assim que nascem. (...) Inconformada, sua esposa arma um plano para salvar Júpiter, o recém-nascido. Ela envolve uma pedra em alguns panos e a apresenta assim para o marido, tentando convencê-lo de que está lhe entregando o filho. Dominado pela gula, ele engole o objeto sem se dar conta do que ocorre, o que demonstra o caráter do tempo, o qual devora e destrói tudo que existe".
} 
duração ilimitada, eterna, recorda o filho que levanta a mão contra sua própria mãe (IHERING, 2009, p. 28).

A terminologia compreende os termos específicos/próprios empregados em determinada área do conhecimento, comunicando seus conceitos. A terminologia jurídica, portanto, consiste nos termos próprios do Direito, bem como em sua conceituação, promovendo, desta forma, a comunicação de um conhecimento especializado (PAVEL; NOLET apud FONSECA).

\begin{abstract}
Apesar de ter sido definida pela International Organization for Standardization (ISO) como qualquer atividade relacionada com a sistematização e representação de conceitos ou apresentação de termos baseados em princípios e métodos estabelecidos e ainda como um conjunto de termos que constituem um sistema de conceitos de uma determinada área, não há um consenso ou uma definição hermética do que vem a ser a terminologia. (...) Em um contexto mais genérico, a terminologia representa o conhecimento técnico-científico especializado de forma organizada, por meio de manuais e glossários, e unifica esse conhecimento sob a forma de normas e padrões. Sem a terminologia, os especialistas não conseguiriam se comunicar, repassar seus conhecimentos, nem tampouco representar esse conhecimento de forma organizada. Nesse sentido, Cabré atribui à terminologia a qualidade de ser a base do pensamento especializado (DIAS, 2000).
\end{abstract}

No contexto do Direito, sem uma terminologia jurídica unificadora do conhecimento jurídico, a comunicação deste resta prejudicada, propiciando injustiças. Ademais, só se afigura possível imaginar a integralidade do fenômeno jurídico através do dinamismo, sendo que a terminologia jurídica não pode estar dissociada dos fatos sociais.

Desta forma, é imprescindível desvendar o conceito de família albergado pela Constituição Federal de 1988, a ser extraído de seu artigo 226, para que o mesmo seja irradiado para todo o ordenamento jurídico, gerando interpretações conforme a matriz constitucional.

Para chegar-se a um conceito de família constitucionalmente correto, há que se conjugar os princípios da pluralidade familiar e da dignidade da pessoa humana, a exemplo do que fez o Supremo Tribunal Federal ao reconhecer o status de entidade familiar às uniões homoafetivas ${ }^{2}$. Assim, devem merecer especial proteção do Estado as famílias matrimoniais, monoparentais, decorrentes de união estável ou de relacionamentos públicos, duradouros, em que há efetivo ânimo de constituir família e preocupação com a proteção e promoção da dignidade de seus membros.

Conforme bem resume Rocha, a abertura do conceito de família e o fato de ser ela um fenômeno social levam à percepção de que a Constituição Federal de 1988 fez com que 
coincidissem, pela primeira vez, o conceito jurídico-positivo de "família" e o significado sociológico deste mesmo vocábulo (2009, p. 5). Complementando esta constatação, Germano explica que

\begin{abstract}
A proteção do Estado à família se expressa das mais variadas formas e mecanismos. O interesse público na tutela de tais propósitos encontra-se na necessidade de se garantir a cada membro integrante da entidade familiar dignas condições de subsistência e assentamento na sociedade, como sujeitos que a formam e que nela estabelecem todas as relações decorrentes de sua própria vivência. Nesse sentido, cabe ao Poder Público, dentre outras ações, garantir e proteger a família através da edição do Direito Positivo, que neste particular nada mais é do que a tutela estatal para com as questões relacionadas a família, enquanto instituição. Antes, a proteção jurídica restringia-se a família concebida através do casamento, não se reconhecendo outras formas capazes de receber, por parte do Estado, especial proteção legal. Após a promulgação da Constituição Federal de 1988, o Poder Público recepcionou a União Estável como entidade familiar, merecendo, dessa forma, por parte de suas estruturas, tutela jurídica e constitucional. Desde então, já não importa a maneira como foi constituída a entidade familiar, apenas interessando, diante de sua caracterização, a obrigação do Estado em protegê-la (2003, p. 157-158).
\end{abstract}

2 Este reconhecimento se deu no julgamento conjunto da Argüição de Descumprimento de Preceito Fundamental 132-RJ e da Ação Direta de Inconstitucionalidade 4277-DF, realizado em 05/05/2011 e publicado em 14/10/2011, tendo como relator o Ministro Ayres Britto. Da ementa deste julgado, oportuna a seguinte passagem: (...) 3. TRATAMENTO CONSTITUCIONAL DA INSTITUIÇÃO DA FAMÍLIA. RECONHECIMENTO DE QUE A CONSTITUIÇÃO FEDERAL NÃO EMPRESTA AO SUBSTANTIVO "FAMÍLIA" NENHUM SIGNIFICADO ORTODOXO OU DA PRÓPRIA TÉCNICA JURÍDICA. A FAMÍLIA COMO CATEGORIA SÓCIO-CULTURAL E PRINCÍPIO ESPIRITUAL. DIREITO SUBJETIVO DE CONSTITUIR FAMÍLIA. INTERPRETAÇÃO NÃO-REDUCIONISTA. O caput do art. 226 confere à família, base da sociedade, especial proteção do Estado. Ênfase constitucional à instituição da família. Família em seu coloquial ou proverbial significado de núcleo doméstico, pouco importando se formal ou informalmente constituída, ou se integrada por casais heteroafetivos ou por pares homoafetivos. A Constituição de 1988, ao utilizar-se da expressão "família”, não limita sua formação a casais heteroafetivos nem a formalidade cartorária, celebração civil ou liturgia religiosa. Família como instituição privada que, voluntariamente constituída entre pessoas adultas, mantém com o Estado e a sociedade civil uma necessária relação tricotômica(...). Imperiosidade da interpretação não-reducionista do conceito de família como instituição que também se forma por vias distintas do casamento civil. Avanço da Constituição Federal de 1988 no plano dos costumes. Caminhada na direção do pluralismo como categoria sócio-político-cultural. Competência do Supremo Tribunal Federal para manter, interpretativamente, o Texto Magno na posse do seu fundamental atributo da coerência, o que passa pela eliminação de preconceito quanto à orientação sexual das pessoas (...). 
Daí a conveniência da metáfora utilizada por Perrot (1993) no sentido de que a família passa a ser um ninho acolhedor e aconchegante, devendo propiciar um ambiente harmônico para que a personalidade de seus integrantes se desenvolva de forma sadia, sendo, portanto, "o centro emocional e social de formação do homem" (SEREJO, 2004, p. 13). Pode-se dizer que, sob uma perspectiva constitucional, a funcionalização social da família "significa o respeito ao seu caráter eudemonista ${ }^{3}$, enquanto ambiência para a realização do projeto de vida e de felicidade de seus membros, respeitando-se, com isso, a dimensão existencial de cada um" (GAGLIANO; PAMPLONA FILHO, 2013, p. 99).

A concretização da função social da família passa, portanto, pelo exercício cotidiano da solidariedade familiar e dos deveres de respeito e de cuidado. Nesse sentido, "a famíliainstituição foi substituída pela família-instrumento, ou seja, ela existe e contribui tanto para o desenvolvimento da personalidade de seus integrantes como para o crescimento e formação da própria sociedade" (DIAS, 2009, p. 43), justificando-se, com isso, a sua proteção pelo Estado.

Sendo este o conceito de família e sua função social esposados pela Constituição Federal, é imperioso que todo o ordenamento jurídico, ao lidar com relações familiares, parta, obrigatoriamente, de tais premissas.

\section{POR UMA RECOLOCAÇÃO DA DOGMÁTICA PENAL - O DIREITO COMO UM SISTEMA IDEALMENTE COERENTE DE PRINCÍPIOS}

Uma compreensão adequada do significado jurídico da proteção especial à família imposta constitucionalmente ao Estado através do art. 226 desnuda completamente o descompasso da legislação penal com o referido propósito, já que, conforme restou demonstrado, este ramo específico da ciência do Direito ainda baseia-se, em alguns dispositivos, na lógica ultrapassada de que apenas o casamento seria forma juridicamente legítima de constituição de família.

Discorrendo sobre a constitucionalização do Direito, Barroso discorre que

\footnotetext{
${ }^{3}$ A busca da felicidade trouxe para o âmbito do Direito das Famílias a expressão "família eudemonista". No grego, eu significa boa e daimons significa demônios ou espíritos, de forma que a palavra eudaimonia significa viver com bons espíritos, o que gera felicidade (ZIMERMAN apud ROSA, 2013, p. 88).
} 
A constitucionalização do direito penal suscita um conjunto instigante e controvertido de ideias, a serem submetidas ao debate doutrinário e à consideração da jurisprudência. (...) Os bens jurídicos constitucionais obedecem a uma ordenação hierárquica, de modo que a gravidade da punição deve ser graduada em função dessa lógica. A disciplina jurídica dada a determinada infração ou a pena aplicável não devem ir além nem tampouco ficar aquém do necessário à proteção dos valores constitucionais em questão (2013, p. 405).

O mesmo autor ressalta, ainda, que "toda interpretação jurídica é, direta ou indiretamente ${ }^{4}$, interpretação constitucional” (2014) e explica que algumas tipificações previamente existentes são questionáveis no cenário atual de Neoconstitucionalismo/Póspositivismo à luz dos novos valores constitucionais e da transformação dos costumes (...), se provocarem resultado constitucionalmente indesejável (2013, p. 404).

Se as Constituições Federais de 1934, 1937 e 1946 consideraram para fins de proteção estatal somente as famílias matrimoniais - o que, logicamente, foi determinante para a elaboração do Código Penal na década de 40 - fato é que a Constituição Federal de 1988 alterou drasticamente este cenário, prevendo a pluralidade familiar em seu art. 226.

De qualquer forma, Pontes de Miranda (apud Rocha, 2009, p. 24), já em 1947, advogava no sentido de que

\begin{abstract}
Se alguma lei ordinária regular o abandono de família (direito civil ou penal), não se protegerá somente a família ligada a um par casado com indissolubilidade do vinculo conjugal, mas, em geral, à família, se bem que caiba à legislatura ordinária fixar os pressupostos para a incidência dos preceitos da lei. Se alguma lei penal considera agravante ato praticado contra pessoa da família do acusado, família não é só aquela em que há o ponto de partida de um casamento a vínculo. Em verdade, há dois conceitos, que foram encambulhados no texto constitucional, sem que de tal associação se possam tirar conclusões contrárias ao interesse da família instituição social, isto é, contrarias ao que a própria Constituição quis proteger em capítulo especial. Seria desconhecer-se o intuito étipo-político do legislador constituinte, que não pretendeu defender só a instituição jurídica, mas a família como instituição social.
\end{abstract}

\footnotetext{
4 “Interpreta-se a Constituição indiretamente quando se aplica o direito ordinário, porque antes de aplicá-lo é preciso verificar sua compatibilidade com a Constituição e, ademais, o sentido e o alcance das normas infraconstitucionais devem ser fixados à luz da Constituição" (BARROSO, 2014).

5 "Segundo o pós-positivismo deve ser observada uma mudança de paradigma, qual seja: de Estado Legislativo de Direito, onde é dada maior ênfase ao princípio da legalidade, para o Estado Constitucional e Democrático de Direito, onde a Constituição é o centro, o norte de todo o sistema jurídico, com valor supremo (ARAKAKI, 2013, p. 125)". "Assim, o que pretende o neoconstitucionalismo é fazer com que a base normativa que sustenta o ordenamento jurídico seja utilizada continuamente, inclusive no que tange ao legislador infraconstitucional e ao interpretador (magistrados na análise do caso concreto), devendo a mesma ser analisada, reanalisada e readequada, dando verdadeira concretização e efetividade à Carta Marga" (ARAKAKI, 2013, p. 128)".
} 
Contudo, ainda que a repercussão do direito constitucional sobre a disciplina legal dos crimes e das penas seja ampla, direta e imediata, não tem sido explorada de maneira abrangente e sistemática pela doutrina especializada (BARROSO, 2013, p. 404). A dogmática penal tradicional, na tentativa de superar o positivismo jurídico e realizar uma exegese do Direito à luz de um Estado Democrático, entende que a partir da interpretação do princípio da legalidade, não é mais possível permitir ao magistrado um “alargamento" dos tipos penais, de causas de aumento de pena, qualificadoras e agravantes, sob pena de incorrer em analogia in malam partem, o que é vedado neste âmbito do Direito.

A doutrina penal enumera quatro funções para o princípio da legalidade. A primeira é proibir a retroatividade da lei penal; a segunda é vedar a criação de crimes e penas pelos costumes; a terceira é proibir o uso da analogia para criar crimes, fundamentar ou agravar penas e, por derradeiro, vedar incriminações vagas e indeterminadas (GRECO, 2015, p.146). Desta forma, atrelando o princípio da legalidade aos sub-princípios da reserva legal, da taxatividade e da anterioridade da lei, entendem que é vedado qualquer recurso que possa criar hipóteses que, de alguma forma, venham a prejudicar o agente.

No escólio de Queiroz, pode-se compreender exatamente o posicionamento acima exposto, uma vez que ensina expressamente que o princípio da reserva legal implica a máxima determinação e taxatividade dos tipos penais, impondo-se ao Poder Legislativo, na elaboração das leis, que redija tipos penais com a máxima precisão de seus elementos, bem como ao Judiciário que as interprete de modo a preservar a efetividade do princípio (2008, p. 23-24).

Nesse diapasão é que a doutrina convencional, se valendo de argumentos como segurança jurídica, vedação a condutas arbitrárias e proteção ao indivíduo, veda qualquer interpretação que extrapole a criação legislativa e, de antemão, enumera todas as interpretações possíveis dos dispositivos penais, estabelecendo um molde interpretativo, a partir do qual todos os demais casos serão interpretados (CHAMON, 2006, p. 94). O que essa tradição não considera é que, submersa a esse tipo de leitura está uma incompreensão do caráter principiológico do Direito que não é alheio ao Direito Penal.

"Se é certo que o Direito Penal incide sobre certos e pontuais fatos recortados argumentativamente, é inegável e imprescindível estabelecer como também o Direito Penal se justifica e se aplica a partir de princípios jurídico-normativos" (CHAMON, 2006, p. 76). Assim, 
(...) a compreensão do princípio da legalidade está atrelada tanto a uma compreensão de que a atividade interpretativa jurisdicional é devedora de um quadro de interpretações possíveis dos tipos penais quanto a uma compreensão naturalista, e não normativa, dos tipos. Em face disso, propomos uma interpretação principiológica do Direito e, também, pois, do próprio princípio da legalidade: afinal, tal empreitada exige uma compreensão de referido princípio como central na caracterização da modernidade do Direito Penal, o que nos conduz a interpretálo como aberto, e não como fechado, ao mundo-da-vida. (CHAMON, 2006, p. 82).

Partindo-se desta premissa, importante elucidar a distinção entre princípios e regras, bem como entender, assim como Dworkin, que o Direito é um sistema idealmente coerente de princípios e que existe uma resposta correta para cada caso.

Canotilho elucida que tanto os princípios quanto as regras são espécies de normas e que aqueles seriam núcleos de condensação nos quais confluem valores e bens constitucionais, sendo normas que "não proíbem, permitem ou exigem algo em termos de tudo ou nada; impõem a optimização de um direito ou de um bem jurídico, tendo em conta a reserva do possível fáctica ou jurídica" (2003, p. 1255). Alexy esclarece que este "âmbito das possibilidades jurídicas é determinado pelos princípios e regras colidentes” (2008, p. 90).

\begin{abstract}
O grau de abstração dos princípios, pois, seria bem maior que o das regras. Isso inevitavelmente levaria os princípios a serem considerados como menos determinantes na aplicação daquilo que se poderia interpretar como juridicamente devido. Menos determinante não se confundiria com menos impositivo: para o autor, seria inegável a força jurídica e impositiva dos princípios. Todavia, por pretensamente serem mais abstratos, por supostamente serem os "pilares axiológicos" da ordem normativa, guardariam um maior distanciamento frente ao dia-a-dia, frente aos conflitos faticamente constatáveis (CHAMON, 2006, p. 74).
\end{abstract}

Conforme ressalta Chamon, nem todas as normas possuem literalidade patente no texto constitucional e infraconstitucional, sendo que muitas normas principiológicas encontram-se ““"escondidas” por detrás de outros princípios ou até mesmo por detrás de uma determinada "regra" convencionada legislativamente" (2006, p. 75).

Para Dworkin - que em "Levando os direitos a sério" propõe um ataque ao positivismo ao se debruçar sobre os desenvolvimentos teóricos de Herbert Hart -,

A diferença entre princípios e regras é de natureza lógica. Os dois conjuntos de padrões apontam para decisões particulares acerca da obrigação jurídica em circunstâncias específicas, mas distinguem-se quanto à natureza da orientação que oferecem. As regras são aplicáveis quanto à maneira tudo-ou-nada. Dados os fatos que uma regra estipula, então ou a regra é válida, e neste caso a resposta que ela oferece deve ser aceita, ou não é válida, e neste caso em nada contribui para a decisão $(2003$, p. 39). 


\begin{abstract}
Os princípios possuem uma dimensão que as regras não tem - a dimensão de peso ou importância. Quando os princípios se intercruzam (por exemplo, a política de proteção aos compradores de automóveis se opõe aos princípios de liberdade de contrato), aquele que vai resolver o conflito tem de levar em conta a força relativa de cada um. Esta não pode ser, por certo, uma mensuração exata, e o julgamento que determina que um princípio ou uma política particular é mais importante que outra frequentemente será objeto de controvérsia. Não obstante, essa dimensão é um aparte integrante do conceito de princípio, de modo que faz sentido perguntar que peso ela tem ou quão importante ela é (DWORKIN, 2003, p. 42).
\end{abstract}

Ocorrendo, desse modo, um fato que se amolda a uma regra, essa última apontará o resultado exato. Já, em relação aos princípios, não haverá essa indicação ou apontamento, mas apenas um direcionamento para qual raciocínio jurídico deve o aplicador pender.

Confrontando esta conceituação de princípios enquanto espécies de norma com o que a doutrina penal entende por princípios, percebe-se um grande descompasso: Feitoza reza que princípios de direito são normas de caráter geral, que se constituem em diretrizes do ordenamento jurídico (2008, p. 113). De semelhante valor são as considerações de Tornaghi ao dizer que princípios seriam dogmas que se inferem do estudo de determinada legislação (1995, p. 26). Por sua vez, Masson preconiza que os princípios são verdadeiros valores fundamentais que irão inspirar a criação e a manutenção do sistema jurídico (2003, p. 5).

Resumindo, a doutrina penal equipara o direito à lei positivada e atrela o significado de princípios à noção de valores, gerando sua fragilização, já que a sociedade Moderna é plural do ponto de vista axiológico - dos valores - e que não existe um ethos compartilhado por todos. Ademais, "uma perspectiva axiológica acaba por tornar o Direito algo extremamente irracional, fruto das vontades dos juízes” (OMMAT MEDAUR, 2012, p.137). Neste cenário, Chamon ressalta que

(...) $\mathrm{O}$ ponto não tão bem aceitável e merecedor de maiores discussões, no que tange ao referido desenvolvimento teórico e também da praxis, consiste na problematização do que podemos, juridicamente, e não simplesmente de uma perspectiva axiológica, interpretar como analogia in bonan partem e in malam partem. A questão adquire novos ares de relevância quando se percebe que não podemos mais validamente pressupor uma ordem concreta de valores "vigentes na sociedade""' (2006, p. 83). 
E continua, afastando a noção de valores do procedimento de realização das analogias in bonam e em malam partem:

\begin{abstract}
Assim é que compreendemos que a chamada "analogia in bonan partem", passível de ser assumida como uma interpretação legítima em face do princípio da legalidade, há que ser interpretada como em favor do réu, não de uma perspectiva valorativa qualquer, mas no sentido de que a interpretação que "beneficia o réu" é aquela que determina, concretamente, a pena adequada, ou até mesmo a não-incidência legítima de sanção qualquer, tomando como cerne o sistema de direitos fundamentais - ainda que de um ponto valorativo para o próprio réu a imposição legítima de certas "sanções", no caso concreto, fossem preferíveis por razões que subjetivamente lhe pertencem, muito embora possam, não obstante, ser problematizadas em termos de coerência e, portanto, veracidade.

Temos, por outro lado, que a figura da "analogia in malam partem" há que ser, pois, compreendida, dentre várias, como aquela interpretação que, sob o argumento tradicional de se pretender "estender" o "âmbito" de aplicação do tipo penal para além daquela interpretação argumentativa e intersubjetivamente sustentável, acaba por, na verdade, concretizar em face de uma dada situação jurídica uma situação interpretativa ilegítima, no sentido de que "em prejuízo" há que se compreender, juridicamente, como aquilo capaz de impor concretizações, em face da especificidade da situação jurídica, desrespeitosas aos direitos fundamentais do réu para além daquelas outras concretizações cabíveis ao caso quando de uma interpretação legítima, e sustentável, pois, do próprio Direito Penal em face do caso (CHAMON, 2006, p. 84-85).
\end{abstract}

Desta forma, a doutrina penal precisa reconfigurar seus conceitos de analogia in

bonam e em malam partem o que, consequentemente, influenciará numa nova compreensão do princípio da legalidade penal.

A praxis do Direito Penal, bem como sua problematização teórica, muito sob a influência direta de uma perspectiva como a da Escola da Exegese, logo se prontificaram em afirmar que o tipo penal haveria que ser claro, óbvio, como forma de se evitar a atividade interpretativa do juiz quando da aplicação do Direito. A dificuldade de sustentação desse ponto de partida logo se fez por todo arruinada quando os chamados "elementos normativos" do tipo penal foram assumidos, por vez, como presentes em vários tipos penais a exigir, exatamente, um esforço interpretativo mais sofisticado dos intérpretes do Direito Penal a fim de se alcançar seu "real" significado. Para nós, torna-se claro que a própria distinção entre elementos normativos/elementos não-normativos do tipo penal mantém-se presa ao ideal de BECCARIA de não interpretação em face de uma clareza textual da própria legislação instituidora de crimes e penas.

Por outro lado, assumimos aqui que todo e qualquer elemento do tipo penal há que ser definitivamente compreendido como normativo, como outrora instituiu WOLF, mas no sentido de que todo e qualquer tipo penal há que ser inteiramente interpretado levando-se em consideração o sistema normativo em seu ideal de coerência. Tal distinção não se sustenta quando se pode perceber que não há mais que se pretender certos elementos cujos sentidos sejam capazes de ser assumidos como "óbvios", ou até mesmo entendidos como elementos "préinterpretativos". O tipo penal há que ser interpretado à luz do sistema de direitos fundamentais, levando-se em consideração, pois, a própria história institucional referida à praxis do Direito Penal, a partir da qual propostas hemenêuticoreconstrutivas podem ser levadas adiante (CHAMON, 2006, p. 85). 
Nota-se, portanto, que a dogmática penal também não pode desconsiderar o contínuo aumento da complexidade social no momento da aplicação da lei. Desta forma, não pode continuar defendendo a taxatividade enquanto sinônimo de clareza textual não problematizável. Nesse sentido, Chamon alerta para o fato de que

(...) a própria assunção dos elementos normativos acabam por abrir as portas exatamente para a problematização da atividade interpretativa do tipo penal, na medida em que torna mais explícito que qualquer atividade de aplicação normativa envolve uma problematização interpretativa em face de um caso concreto. Tradicionais expressões do nosso Direito Penal como "mulher honesta", "adultério", "indevidamente", dentre inúmeras outras, eram assumidas como abertas à interpretação regional e temporal, supostamente porque os elementos não-normativos tinham pretensões de "universalidade" e "atemporalidade".

Tudo isso se encontra diretamente envolvido com a pretensão de, através da assunção de um tipo penal, se abarcar todas as hipóteses cabíveis ao Direito Penal. Isto fora pressuposto, e assim o vem até os dias de hoje, assumindo o Direito como um sistema de regras convencionadas, em que todo o resto não convencionado estaria excluído: seja porque não há uma figura típica que se perfaz como adequada ao caso, seja porque, além desse motivo, desde antes se entende que o tipo não pode ser "interpretado" para alem daquelas leituras inequívocas e óbvias que desde sempre foram ao mesmo referidas. Afinal: podemos realmente reduzir a compreensão do Direito como um sistema de regras ao molde convencionalista? É válida a assertiva de se pretender oferecer, ex ante, as interpretações possíveis de uma norma jurídica? Perceberemos que a compreensão da teoria da interpretação do tipo penal é bastante devedora também de uma compreensão positivista do Direito (CHAMON, 2006, p. 86-87).

A problemática na qual a dogmática convencional se encontra presa se deve a uma compreensão do Direito aos moldes positivista, que assume a interpretação do Direito Penal atrelada a um quadro de possíveis interpretações (CHAMON, 2006, p. 104).

Ao fazer coincidir os conceitos de normas e regras, relegando os princípios à condição de meros valores e estabelecendo previamente as possíveis leituras de um tipo penal através da fixação uma moldura que contém todas as interpretações possíveis, aquela deixa de levar em consideração que novas situações ou novos casos podem surgir a qualquer momento, a exemplo do que ocorre com o conceito de família e, portanto, de relações familiares.

Enxergar o Direito como um sistema idealmente coerente de princípios implica afirmar que o Direito é completo, que não existem lacunas (dessa forma não importa o conceito de analogia in malam partem ou in bonam partem, já que analogia implica em compreender o Direito como possuindo lacunas) e que a única fonte do Direito é o próprio Direito. Se lacunas não há, a resposta correta, para cada caso, está dentro do próprio Direito, bastando ser desvelada ou "descoberta", jamais "criada". 
É assim que, se encampados forem os ensinamentos de Dworkin, o fato de se interpretar o(a) companheiro(a) como sendo parte integrante da alínea "e" do inciso II do art. 61 do Código Penal, por exemplo, não consiste em admitir uma analogia in malam partem, mas assumir o Direito como um sistema coerente de princípios em que a Constituição "não é só técnica. Tem que haver, por trás dela, a capacidade de simbolizar conquistas e de mobilizar o imaginário das pessoas para novos avanços" (BARROSO, 2005). Isso importa dizer que todo caso terá que ser problematizado e que a resposta correta será encontrada após a reconstrução argumentativa dos fatos, que não existe uma resposta pronta, já que os princípios não elencam um rol de respostas prévias, mas, apenas, apontam um direcionamento para qual raciocínio jurídico deve o aplicador pender.

Contextualizando tais conclusões no âmbito da temática do presente estudo, e considerando que o conceito de família não se restringe ao de família matrimonial, pode-se afirmar que em todos os casos apontados anteriormente que prevêem expressamente a aplicação da lei penal apenas à figura do cônjuge, desconsiderando as outras formas de união amorosa, deveriam ser interpretados de forma a englobá-las.

Frise-se que esta postura já vem sendo assumida para restringir direitos no âmbito da interpretação das hipóteses legais de inelegibilidade elencadas no $\S 7^{\circ}$ do art. 14 da Constituição Federa. Conforme elucida Madaleno,

É meridiana a incompatibilidade material entre a candidatura a cargo público na condição de cônjuge, de convivente ou de parente do titular do cargo executivo posto em disputa, mesmo porque, visando inibir o tráfico de influência e o continuísmo eleitoral, não se apresenta afastada a transferência do prestígio eleitoral ao convivente do administrador a ser sucedido, apenas porque não envolto com o seu parceiro, agora candidato, pelas lícitas núpcias do matrimônio formal. Não há como pensar de outro modo quando esta mesma influência decorre exatamente da afetividade que os uniu pelo casamento formal ou mesmo informal, mas sempre pela vinculação afetiva que permitiu unir seus corpos e seus sentimentos numa união semelhante a de marido e de mulher, conformada aos olhos de todos em uma nítida e incontestável entidade familiar, como aliás, já há bastante tempo havia decidido o TSE via da Resolução $\mathrm{n}^{\circ} 18.086$, de 23.4.92, sendo Relator o Ministro Américo Luz, com a seguinte ementa: "A Constituição atual estende o conceito de entidade familiar quando expressa no seu art. 226, § $3^{\circ}$ : 'Para efeito de proteção do Estado é reconhecida a união estável entre homem e mulher como entidade familiar, devendo a Lei facilitar sua conversão em casamento'. Diante, portanto, desse império constitucional, esta Corte considera que a união gera inelegibilidade, diante do art. $14, \S 7^{\circ}$, da CF".

Segundo explica Fachin, 


\begin{abstract}
As questões pertinentes ao parentesco - bem como, de um modo geral, aquelas que dizem respeito às relações de direito de família - não podem ser examinadas sem levar em conta o fato de que a família é realidade que antecede o direito. Esse fato implica a necessidade de que, ao versar a respeito do tema, o operador e o estudioso do direito tomem em consideração a necessária abertura do sistema jurídico para os fatos da vida concreta, que ensejam a construção simultaneamente tópica e sistemática de soluções não previamente previstas (de modo estrito) no direito legislado.

A porosidade do sistema jurídico é assegurada pela maior abertura propiciada pelos princípios e valores que informam e estruturam o sistema, sendo, pois, indispensável o enfrentamento do desafio de (re)construção do direito a partir de sua ordem principiológica (2008, p. 269).
\end{abstract}

Sendo a família constitucionalmente erigida sobre o respeito à pluralidade e já estando há muito ultrapassada sua noção de legitimidade atrelada unicamente ao vínculo matrimonial (haja vista o texto constitucional de 1988), não é cabível que a dogmática penal ignore tais fatos na aplicação da lei penal sob o argumento da vedação da analogia in malam partem, desvirtuando o real sentido desta.

\title{
5 CONSIDERAÇÕES FINAIS
}

Eu sou partidário da audácia intelectual. Nós não podemos ser intelectualmente covardes e ao mesmo tempo buscar a verdade. Aquele que busca a verdade deve ousar ser sábio - ele deve ousar ser um revolucionário no campo do pensamento. (POPPER, 1999, p. 92)

Diante da regra constitucionalmente expressa de que a família é a base da sociedade, merecendo especial proteção do Estado, pode-se afirmar que tal mandamento deve informar todo o ordenamento jurídico. Atenta a esta garantia, a própria Constituição Federal adotou o princípio da pluralidade familiar que, embora constitucionalmente implícito, resguarda direitos a todas as entidades familiares e não somente àquelas expressamente listadas no texto constitucional a título exemplificativo.

Ocorre que a dogmática penal não absorveu esta democratização da família e, diante da abertura atual deste conceito, interpreta sua aplicação prática como sendo analogia e o pior, analogia in malam partem.

É consabido que a analogia é um recurso de integração da lei a ser utilizado quando houver lacunas na mesma. Conforme defendeu-se aqui, enxergar o Direito como um sistema idealmente coerente de princípios e regras implica concluir que o mesmo é 
completo, que não existem lacunas, e que a resposta correta para cada caso concreto está dentro do próprio Direito, bastando ser desvelada, jamais criada.

Portanto, em todos os casos aqui apontados em que há previsão expressa de aplicação da lei penal apenas à figura do cônjuge, desconsideradas outras formas de união amorosa, a atividade do hermeneuta deve ser no sentido de englobar estas últimas, realizando uma leitura principiológica do princípio da legalidade.

\section{REFERÊNCIAS}

ALEXY, Robert. Teoria dos Direitos Fundamentais. Trad. Virgílio Afonso da Silva. 2 ed. São Paulo: Malheiros, 2008.

ARAKAKI, Fernanda Franklin Seixas. Neoconstitucionalismo: axiologia dos direitos fundamentais. In: COELHO, Márcio Xavier (Coord.). Estado e sociedade: 25 anos da Constituição Cidadã. Belo Horizonte: Del Rey, 2013, p. 117-129

BARROSO, Luís Roberto. Curso de direito constitucional contemporâneo: os conceitos fundamentais e a construção do novo modelo. $4^{\mathrm{a}}$. Ed. São Paulo: Saraiva, 2013.

. Grandes transformações do Direito Contemporâneo e o pensamento de Robert Alexy, 2014. Disponível em: http://www.luisrobertobarroso.com.br/?p=1003. Acesso em: $12 / 03 / 2016$.

BRASIL, Supremo Tribunal Federal. Argüição de Descumprimento de Preceito Fundamental 132-RJ e Ação Direta de Inconstitucionalidade 4277-DF sobre o reconhecimento das uniões homoafetivas como entidades familiares. Rel Min. Ayres Britto. Julgadas em 05/05/2011. Publicado em 14/10/2011. Disponível em: http://redir.stf.jus.br/paginadorpub/paginador.jsp?docTP=AC\&docID=628633

CANOTILHO, José Joaquim Gomes. Direito constitucional. Coimbra: Almedina, 2003.

CHAMON JÚNIOR, Lúcio Antônio. Teoria constitucional do direito penal: contribuições a uma reconstrução da dogmática penal 100 anos depois. Rio de Janeiro: Lumen Juris, 2006.

CUNHA, Rogério Sanches. Manual de direito penal: parte especial. $3^{\mathrm{a}}$. ed. Salvador: JusPodivm, 2015.

DIAS, Maria Berenice. Manual de direito das famílias. $5^{\mathrm{a}}$. ed. rev., atual. e ampl. São Paulo: Editora Revista dos Tribunais, 2009.

DIAS, Cláudia Augusto. Terminologia: conceitos e aplicações. In: Ciência da Informação, vol. 29, Brasília, Jan./Abr. 2000. Disponível em: http://www.scielo.br/scielo.php?pid=S0100-19652000000100009\&script=sci_arttext. Acesso em: 25/03/2016. 
DWORKIN, Ronald. Levando os direitos a sério. Trad. Nelson Boeira. 3 ed. São Paulo: WMF Martins Fontes, 2010.

$\overline{\text { Fontes, } 2003 .}$

O Império do Direito. Trad. Jefferson Luiz Camargo. São Paulo: Martins

FACHIN, Luiz Edson. Vínculo parental parabiológico e irmandade socioafetiva. In: Questões do direito civil brasileiro contemporâneo. Rio de Janeiro: Renovar, 2008, p. 267296.

FEITOZA, Denílson. Direito processual penal: teoria, crítica e praxis. Niterói: Impetus, 2008.

FONSECA, Luciana Carvalho. A terminologia jurídica e a tecnologia. In: Migalhas, 26/10/2009.Disponível em: http://www.migalhas.com.br/LawEnglish/74,MI95721,101048A+Terminologia+Juridica+e+a+Tecnologia . Acesso em: 25/03/2016.

GAGLIANO, Pablo Stolze; PAMPLONA FILHO, Rodolfo. Novo curso de Direito Civil, vol. 6: Direito de Família - as famílias em perspectiva constitucional. $3^{\text {a }}$ Ed. rev., atual. e ampl. São Paulo: Saraiva, 2013.

GERMANO, Luiz Paulo Rosek. Deveres constitucionais da família frente ao Estado. In: PORTO, Sérgio Gilberto; USTÁRROZ, Daniel (Orgs.). Tendências constitucionais no direito de família: estudos em homenagem ao Professor José Carlos Teixeira Giorgis. Porto Alegre: Livraria do Advogado, 2003, p.155-167.

GRECO, Rogério. Curso de Direito Penal: parte geral, vol. 1.17 ed. Niterói: Impetus, 2015.

IHERING, Rudolf Von. A luta pelo Direito. Tradução João de Vasconcelos. São Paulo: Martin Claret, 2009.

LIMA, Renato Brasileiro. Manual de Processo Penal. 3a . Ed. Salvador: JusPodivm, 2015.

MADALENO, Rolf. A inelegibilidade eleitoral na união estável. Disponível em: http://www.rolfmadaleno.com.br/novosite/conteudo.php?id=49. Acesso em 24/03/2016.

MASSON, Cleber. Código Penal comentado. Rio de Janeiro: Método, 2003.

. Código Penal comentado. 2 ed. rev. atual e ampl. Rio de Janeiro: Método, 2014.

NUCCI, Guilherme de Souza. Manual de direito penal. 10 ed. Rio de Janeiro: Forense, 2014.

OMMATI MEDAUR, José Emílio. Liberdade de Expressão e Discurso de Ódio na Constituição de 1988. Rio de Janeiro: Lumen Juris, 2012.

PERROT, Michelle. O nó e o ninho. O nó e o ninho. In: HARAZIN, D. (Org.). Veja 25 anos - reflexões para o futuro. São Paulo: Abril, 1993, p. 74-81. 
POPPER, Karl. Lógica das ciências sociais. 2a . ed. Rio de Janeiro: Tempo Brasileiro, 1999.

QUEIROZ, Paulo de Souza. Direito Penal: Parte geral. 4 ed. Rio de Janeiro: Lumen Juris, 2008.

ROCHA, Fernando A. N. Galvão da. Direito Penal - Parte Geral. Niterói: Impetus, 2004.

ROCHA, Marco Túlio de Carvalho. O conceito de família e suas implicações jurídicas: teoria sociojurídica do Direito de Família. Rio de Janeiro: Elsevier, 2009.

ROSA, Conrado Paulino da. iFamily: um novo conceito de família? São Paulo: Saraiva, 2013.

SANTANA, Ana Lúcia. Saturno (deus romano). Disponível em: http://www.infoescola.com/mitologia/saturno-deus-romano/. Acesso em: 19/03/2016.

SEREJO, Lourival. Direito constitucional da família. Belo Horizonte: Del Rey, 2004.

TORNAGHI, Hélio. Curso de Direito Processual Penal. São Paulo: Saraiva, 1995. 